\title{
UK court gives green light to trial of modified maize
}

[LONDON] The UK campaign for a moratorium on commercial genetically modified crops suffered a setback last week when a farmer failed in his bid to halt a trial of genetically modified maize planted next to his crop of organically grown sweetcorn.

The farmer, Guy Watson, has appealed against the decision by the High Court in London to allow the experimental trial in Devon to continue. He is being backed by the environmentalist group Friends of the Earth and the Soil Association, which certifies his organic produce (see Nature 394,$8 ; 1998$ ).

Watson says he hopes the trial, by the company Sharpes Seeds, can be stopped before the flowering season starts next week. He argues that pollen from the genetically modified maize could pollinate his own crop, which would lose its organic certificate.

But the court ruled that cross-pollination was unlikely, as Watson's sweetcorn is two kilometres away from the genetically modified maize. The decision was based on advice from the government's advisory committee on releases to the environment (ACRE), whose members concluded that cross-pollination was "likely to be zero".

Despite the decision, and the scepticism of most ACRE members about any significant threat to human health from genetically modified crops, the British government remains under pressure to adopt a moratorium on their commercial introduction.

Last week, for example, English Nature, the government's official conservation advisory body, reiterated a call for a three-year moratorium on their commercial release "until current research on their potential effects has been completed and analysed."

"We are certainly not against the development of genetically modified organisms," says Brian Johnson, English Nature's adviser on issues affecting genetic modification. "But we are concerned that their introduction should take place carefully and against a

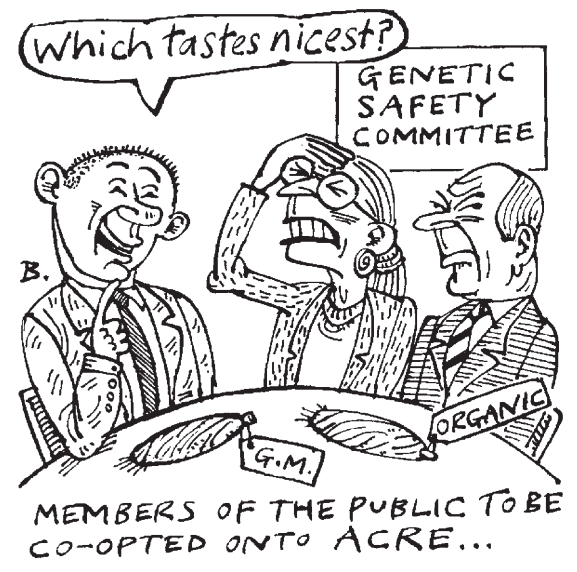

background of sound knowledge."

Chris Haskins, chairman of Northern Foods and Express Dairies, said a three-tofive-year moratorium was needed to give the public time to regain confidence in government scientific opinion.

The question of public confidence in the government's scientific advisers attracted widespread media attention last week when Friends of the Earth pointed out that six of ACRE's thirteen members had interests in companies or organizations that had applied to the committee for licences for trials.

The environmentalist group also pointed out that no application for a trial licence has yet been recommended for refusal. "How can people have confidence in the government advisory panel when so many members have close financial links to the biotech industry?" asks Adrian Bebb, a food campaigner with Friends of the Earth.

But John McLeod, an ACRE member and director of the National Institute for Agricultural Botany, which is conducting the Devon trial on behalf of Sharpes Seeds, says that relevant ACRE members leave the room and do not look at paperwork when the committee discusses licensing applications from organizations with links to ACRE members.

McLeod says this conflict of interest is not of his - or his colleagues' - making. They are appointed to ACRE on the basis of their expertise in assessing the risks of genetically modified crops, but must apply to the same committee for licenses for their own research.

The government has not yet responded officially to the controversy, except to say that it takes the issue seriously and will "shortly" issue a response to public concern about the ethical implications of commercial genetically modified crops. Some changes are already underway, for example 11 ACRE members will be replaced next year, with more members being drawn from the public.

The move is welcomed by Julie Hill of the Green Alliance, the only ACRE member from an environmentalist group, who argues that many members, although of the highest professional integrity, "are 'pro-technology', which colours their view on how they judge the acceptability of a risk."

Many members say the committee needs more experts with experience of research into the implications of genetically modified organisms. Andrew Watkinson, professor of ecology at the University of East Anglia, and an ACRE member until 1993, says "The committee handles some very technical issues in molecular biology, which environmentalists and ecologists would find difficult to comment on."
EhsanMasood

\section{Britain ignores warning on privatization of defence research}

[LONDON] The British government appears set to press ahead with plans to introduce some form of private management of its Defence Research Agency (DERA), against the advice of the House of Commons defence select committee.

In a long-awaited review of Britain's defence policy - the Strategic Defence Review, published last week - the government does not rule out further private-sector involvement in defence research.

The review was released a day after the defence select committee, in its own report on DERA, warned the government against inviting private companies to manage DERA and its affiliated agencies, such as the chemical and biological defence establishment at Porton Down.

But the government's review fails to provide any additional detail on DERA's future beyond what is known already. Ministers have said the agency's fate lies somewhere between total privatization and the status quo, in which it remains part of the Ministry of Defence and is run by the government.

One set of alternatives would involve allowing private companies to manage DERA, or its affiliated organizations, and activities. This arrangement would be similar to other government-owned but privately managed laboratories, such as the National Physical Laboratory in Teddington.

A second alternative is a 'public-private partnership', in which a facility or service is paid for by the private sector, with the government paying for the cost of use. The recently announced supercomputer service for UK academics will be provided in this way (see Nature 394, 114; 1998).

A privately run DERA, the select committee report says, could damage DERA's relations with industry. At present, the agency is seen to be impartial in the work it performs and the advice it gives, both to industry and government. Private-sector management could change that, as the agency will continue to compete with industry for the Ministry of Defence's research programmes.

International research collaboration could also be a casualty of increasing privatesector involvement in DERA, according to the report. Committee members say the US government, for example, is keen on transatlantic research cooperation.

The members also conclude in the report that international collaboration "would be seriously at risk if privatization of DERA proceeded." Julian Brazier (Conservative, Canterbury), a member of the select committee, says that "the committee's message is very clear: leave DERA alone.” Ehsan Masood 